\title{
Hilferding e o Nexo Imperialista entre Capital Financeiro e Exportação de Capital ${ }^{*}$
}

\author{
Fábio Antonio de Campos ${ }^{\dagger}$ \\ Mauricio de S. Sabadini ${ }^{\ddagger}$
}

\begin{abstract}
Resumo
O objetivo desse artigo será mostrar como a relação definida por Hilferding entre o capital financeiro e a exportação de capital estabelece o nexo imperialista que dá sentido à gênese do capitalismo moderno e sua projeção futura, incluindo a relação de dependência entre os países do centro e da periferia. Para tanto, identificaremos as formas de exportação de capital a partir da dinâmica de reprodução do capital financeiro, além de apresentar os elos essenciais que integram a articulação imperialista entre o capital financeiro em seu surgimento histórico, bem como sua internacionalização via exportação de capital. Estabelecemos formas da exportação de capital como os lucros diferenciais e de fundador, investimento de portfólio, empréstimos e investimentos diretos estrangeiros, atualizando um instrumental característico da fase monopolista do capitalismo. Por fim, indicamos possíveis elos que associam parte das ideias de Hilferding à complexidade atual da financeirização e de sua manifestação imperialista.
\end{abstract}

Palavras-chave: Hilferding, capital financeiro, exportação de capital e imperialismo.

JEL: B1; G00; N2

\section{Introdução}

Circunscrita à intensa atuação do capital fictício na economia mundial, bem como pela conquista de amplos espaços de acumulação com elevada exploração do trabalho, a financeirização atual produz as principais estruturas de dominação nas quais o imperialismo se renova. Intermediada por uma somatória de antagonismos sociais, a relação

\footnotetext{
*Agradecemos os comentários e sugestões dos pareceristas anônimos, bem como dos professores Eduardo Mariutti (IE-Unicamp) e Márcio Lupatini (UFVJM), eximindo-os, obviamente, dos possíveis problemas que o artigo apresenta.

†Doutor em Desenvolvimento Econômico pela Universidade Estadual de Campinas (Unicamp), Professor do Instituto de Economia da UNICAMP.

${ }^{\ddagger}$ Doutor em Economia pela Universidade Paris 1 Panthéon-Sorbonne (França), Professor do Departamento de Economia e do Programa de Pós-Graduação em Política Social da Universidade Federal do Espírito Santo (UFES).
} 
entre capital financeiro e imperialismo, além de estar no cerne da constituição moderna do capitalismo, continua viva em sua fase contemporânea. Desse modo torna-se indispensável revisitar os autores que pioneiramente traçaram as linhas mestras de compreensão desse fenômeno originado no século XIX. Dentre as várias contribuições que analisaram o imperialismo, escolhemos Rudolf Hilferding e sua clássica obra O Capital financeiro de 1910 para investigarmos.

A apropriação analítica de Hilferding para explicar o imperialismo, como resultado da concentração e centralização do capital que gestaram o capital financeiro, conduzindo a expansão de mercados em meio às rivalidades estatais que se transformaram em guerras, reformas e revoluções, constitui também em si uma formulação clássica, presente em importantes autores marxistas como Rosa Luxemburg, Lênin, Kautsky e Bukharin ${ }^{1}$. A atualização e confronto histórico da teoria desses autores com base na utilização epistemológica dos conceitos de Hilferding podem ser encontrados em estudos como os de Brewer (1990) e Brown (1978). Já a abordagem específica do capital financeiro em Hilferding, seu alcance e os limites para compreensão do capitalismo contemporâneo, aparecem em autores como Lapavitsas (2006), Milios (s/d) e Pinto (1994; 1997), dentre outros. No entanto, mesmo que alguns trabalhos recentes tenham revisitado essa herança de Hilferding, deslocando qualitativamente as fronteiras de pesquisa ${ }^{2}$, consideramos que é necessário avançar mais nas investigações que estabeleçam organicamente os vínculos imperialistas entre a dinâmica do capital financeiro e a exportação de capital.

Assim, temos por objetivo entender na obra de Hilferding o nexo imperialista que articula o desenvolvimento do capital financeiro com a exportação de capital. Para tanto, torna-se imprescindível, por um lado, refletir como que do movimento intrínseco de valorização do capital financeiro criam-se as necessidades para extroversão, daí apresentarmos suas formas, desde as mais fetichizadas até as mais produtivas. Ao fazermos essa abordagem, extraindo os condicionantes universais que permitem interpretar Hilferding à luz do capitalismo contemporâneo, apresentaremos, por outro lado, a articulação imperialista entre o capital financeiro, definido por sua unidade, mobilidade e antagonismo, e a exportação de capital. Está fora do escopo deste trabalho, todavia, fazer uma contextualização histórica que teste as próprias interpretações empíricas do autor, ou tente medir concretamente seus conceitos de forma exaustiva. Nesse sentido, nossa preocupação é entender a lógica categorial intrínseca ao autor e as derivações históricas que ele próprio fez em sua época, ilustrando quando possível apenas alguns elementos contemporâneos que sinalizem, preliminarmente, a atualidade de seus pressupostos teóricos.

Partindo dessas premissas, nossa hipótese é que se Hilferding indicou as contradições existentes na combinação entre a concentração e centralização do capital, a concorrência, a política protecionista, a exportação de capital e a dominação dos espaços econômicos

\footnotetext{
${ }^{1}$ Vários autores não marxistas também contribuíram para esse debate, em que destacadamente John Atkinson Hobson (1981; 1983) exerceu forte influência em Lênin (1979).

${ }^{2}$ Dentre os quais, destacamos Franco (2011), Corrêa (2012), Mariutti (2013), Pereira (2013) e Sabadini (2015).
}

Econômica-Niterói, v. 20, n. 2, p. 135-158. Dezembro, 2018 
pelo capital financeiro, num dado momento histórico do capitalismo, notamos, ao mesmo tempo, que essas temáticas ainda se fazem presente na atual configuração do sistema capitalista. A nosso ver, um desses condicionantes, por exemplo, se refere ao recente processo de expansão da esfera financeira do capital que tem no capital fictício sua maior representação, procurando, por um lado, se apropriar do excedente criado na produção e, mesmo que contraditoriamente, a máxima simplificação desejada pelo capital, isto é, o extremo D - D'. Da mesma maneira, se Hilferding analisou esta expansão financeira a partir do capital acionário tendo como lócus de acumulação os bancos e monopólios não-financeiros ("industriais"), notadamente as Sociedades Anônimas (SA's), outras formas de capital fictício também contribuíram e continuam a contribuir para o processo de valorização. Citamos as ações e títulos da dívida pública, exemplos clássicos de capital fictício. Soma-se a isso, a introdução de novos atores financeiros na atualidade, para além dos bancos, que também concorrem e fazem parte da complexa rede de relações socioeconômica e política das finanças internacionais, os investidores institucionais, formados pelos fundos de pensão, fundos de investimentos, companhias seguradoras etc.

Com o propósito de extrair o potencial de Hilferding acerca das raízes do capital monopolista, calibrando a análise de questões que nos desafia contemporaneamente, nosso artigo, após essa breve introdução, se inicia pela reflexão do capital financeiro, exportação de capital e as principais formas de valorização no exterior: lucro de fundador, lucros diferenciais, empréstimos, investimento direto estrangeiro (IDE) e portfólio. Na segunda parte, mostraremos a integração dessas formas com base no fenômeno do imperialismo descrito pelo autor. Por último, faremos uma breve conclusão.

\section{Capital Financeiro e Exportação de Capital}

Para entender o imperialismo, Hilferding se baseia em um conceito que ocupa posição central em sua obra. Trata-se da exportação de capital que passa a substituir a noção de exportação de mercadorias, prevalecente até então. Hilferding (1985, p. 296) diz o seguinte sobre o termo:

\footnotetext{
entendemos por exportação de capital a exportação de valor destinado a gerar mais-valia no exterior. Nisso, é essencial que a mais-valia fique à disposição do capital interno. (...) Somente se pode falar de exportação de capital quando o capital empregado no exterior permanece à disposição do país investidor e quando os capitalistas nacionais podem dispor da mais-valia produzida por esse capital no estrangeiro. (...) Portanto, a exportação de capital reduz a quantidade nacional de capital e aumenta a renda nacional pela mais-valia produzida.
}

Por estas palavras, Hilferding associa diretamente o conceito de exportação de capital ao de geração de mais-valia, ou seja, da produção de riqueza sistêmica advinda da exploração da força de trabalho e também a condiciona à necessidade desta permanecer “à 
disposição do país investidor e quando os capitalistas nacionais podem dispor da maisvalia produzida por esse capital no estrangeiro" (Idem). Ao fazer isso, o autor relaciona tal categoria diretamente ao capital produtivo, analisando mais detidamente os investimentos feitos nas diversas atividades produtivas das sociedades anônimas construtoras de ferrovias, exploradoras de minas, dentre outras.

Se isso nos parece convincente, não significa dizer, evidentemente, que a esfera de circulação do ciclo global não faça parte de suas análises. Muito pelo contrário. Hilferding dedica boa parte de sua obra diretamente à análise do Livro III de O Capital, com destaque especial a uma das formas do capital fictício, os títulos de propriedade (ações). Assim, a criação de SA's implica uma contrapartida direta entre investimentos reais, produtivos, e, ao mesmo tempo, crescimento de capital fictício representado pelas ações. As esferas real e financeira se constituem numa relação simbiótica.

De todas as formas, determinado tipo de capital fictício guarda, em sua origem, certa ligação com a atividade produtiva. Porém, seu jogo especulativo assume proporções, detalhadas por Marx no Livro III, no qual a multiplicação de riqueza fictícia ultrapassa a geração de valor. Nesse caso, a aproximação com a produção de riqueza real se distancia, representando o puro jogo especulativo, espaço no qual as ações se valorizam e desvalorizam intensamente no mercado secundário ${ }^{3}$.

Hilferding, ao tratar do capital fictício, está relacionando diretamente a análise do imperialismo ao seu conceito de capital financeiro. E aqui existe uma questão que é importante ser destacada: a ambiguidade do conceito de capital financeiro na obra de Hilferding, que nos permite fazer diferentes leituras. Por mais que esta discussão seja infindável e que talvez o mais importante seja captar em que sentido este conceito nos ilumina para entender o capitalismo contemporâneo, como nos chama atenção Mariutti (2013), o fato é que o capital financeiro passa a ser um elo determinante no processo de exportação de capitais. Evidentemente, seu objetivo principal, via concorrência, é a busca pela acumulação.

De fato, o capital financeiro criou internamente as condições para a exportação de capital, aumentando a importância de novos espaços econômicos que são importantes para a dinâmica da acumulação capitalista. Assim, "a evolução para o capital financeiro eleva a importância da magnitude do espaço econômico" (HILFERDING, 1985, p. 293) e "a evolução em direção ao capital financeiro criou nesses países [Alemanha, Estados Unidos] um forte impulso para a exportação de capital” (idem, p. 303). A exportação de capital, por mais que Hilferding tenha associado diretamente à geração de mais-valia, como vimos anteriormente, tem também seus laços atados com o desenvolvimento da esfera financeira do ciclo global, sobretudo com o desenvolvimento do capital acionário, via trustes e cartéis. Para o autor, "o protecionismo de cartel é o impulso mais forte para

\footnotetext{
${ }^{3}$ Como diz Chancellor (2001, p. 11), “a linha divisória entre especulação e investimento é tão tênue que já disse que especulação é o nome dado a um investimento fracassado e que investimento é o nome dado a uma especulação bem-sucedida".
}

Econômica-Niterói, v. 20, n. 2, p. 135-158. Dezembro, 2018 
o aumento da exportação de capital e conduz necessariamente à política expansionista do imperialismo" (HILFERDING, 1985, p. 342), em que pese, evidentemente, ser a lógica da acumulação capitalista a origem de toda a dinâmica imperialista.

Quando associa a discussão sobre a exportação de capital à produção de mais-valia, Hilferding parece que dá mais espaço para a base produtiva, destacando menos a exportação de capital sob a forma de empréstimo. Mas isso não significa dizer, evidentemente, que ele ignora este último. Para ele, "a exportação pode-se dar de duas formas: o capital emigra ao estrangeiro, como capital produtor de lucro ou de juros (grifo nosso). Neste último caso, pode ainda atuar como capital industrial [produtivo], bancário ou comercial" (HILFERDING, 1985, p. 296) ${ }^{4}$. E vai ser "a estreita união entre o capital bancário e o industrial que fomenta rapidamente esse desenvolvimento da exportação de capital”. Vejamos que aqui Hilferding está relacionando o conceito de capital financeiro à junção entre o capital produtivo e o capital bancário, sendo que as taxas de lucro e de juros funcionam como determinações fundamentais da exportação de capital.

Em outro momento, Hilferding sugere que "é mais vantajoso para um país exportar seu capital em forma de produtor de juros (grifo nosso), visto que o lucro é maior do que

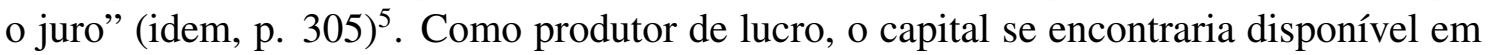
caráter mais imediato e com controle mais direto. Acontece, porém, que a exportação de capital estava representada principalmente pelos trustes e cartéis via companhias ferroviárias, nas empresas de exploração de minas, nas usinas elétricas, etc, que tinham ao seu lado os grandes bancos, simbolismo da junção e formação do capital financeiro. E é nessa associação, tendo por base a constituição do capital acionário, que Hilferding destaca um elemento-chave em suas análises, qual seja: o lucro de fundador.

Diz o autor: "a associação entre os bancos e a indústria é nesse caso muito firme, e a possibilidade do lucro de fundação pela emissão de ações de empresas torna-se um forte

\footnotetext{
${ }^{4}$ Aqui, notamos um erro de tradução na versão em português. A edição francesa, que se apresenta da mesma forma que a inglesa, diz o seguinte: «L'exportation du capital peut, du point de vue du pays exportateur, se faire sous deux formes : le capital émigre à l'étranger en tant que capital portant intérêt ou rapportant un profit. En tant que créateur de profit, il peut fonctionner comme capital industriel, commercial ou bancaire» (HILFERDING, 1970, p. 192). (tradução: “A exportação de capital pode-se dar, do ponto de vista do país exportador, sob duas formas: o capital emigra ao estrangeiro como capital portador de juros ou lucro (grifo nosso). Como criador de lucro (grifo nosso), ele pode funcionar como capital industrial, comercial ou bancário".

${ }^{5}$ Novamente encontramos aqui inconsistências teóricas derivadas de traduções. Vejamos novamente a edição francesa: «il est plus avantageux pour un pays d'exporter ses capitaux sous forme de capital industriel que sous forme de capital de prêt, car le profit est plus élevé que l'intérêt» (HILFERDING, 1970, p. 197). Tradução: “(...) é mais vantajoso para um país exportar seus capitais sob a forma de capital industrial [capital produtivo, produtor de lucro] (grifo nosso) ao invés da forma capital de empréstimo, já que o lucro é maior do que o juro". Duas coisas devem ser ressaltadas: em primeiro lugar, não é exportar capital em forma de juros, mas sim em forma de lucro já que logo depois se afirma, nas duas traduções, que o "lucro é maior do que o juro"; segundo, na versão brasileira, assim como na inglesa, o termo foi traduzido como capital produtor de juros, o que, em princípio, refere-se ao capital a juros, ou portador de juros de Marx. Já na edição francesa, o termo está relacionado ao capital de empréstimo.
} 
motivo para a exportação de capital" (HILFERDING, 1985, p. 305) e, consequentemente, para a implantação da política imperialista. Na verdade, o próprio desenvolvimento do capital acionário associado às empresas cartelizadas dá a constituição ao lucro de fundador, que é uma forma de capital fictício.

\subsection{Lucro de Fundador}

O lucro de fundador aparece em sua obra no capítulo VII - "A sociedade anônima", a partir da transformação das funções do capitalista que passa a atuar de maneira mais vinculada aos movimentos do capital dinheiro e acionista da empresa nas bolsas de valores. Sua figura agora é aquela proprietária de papéis que lhe dão direitos a dividendos futuros. A nosso ver, sua origem está vinculada às duas dimensões sistêmicas do ciclo global: as esferas real e financeira, como pode ser observado na figura seguinte:

Figura 1 - O modelo global e o lucro de fundador

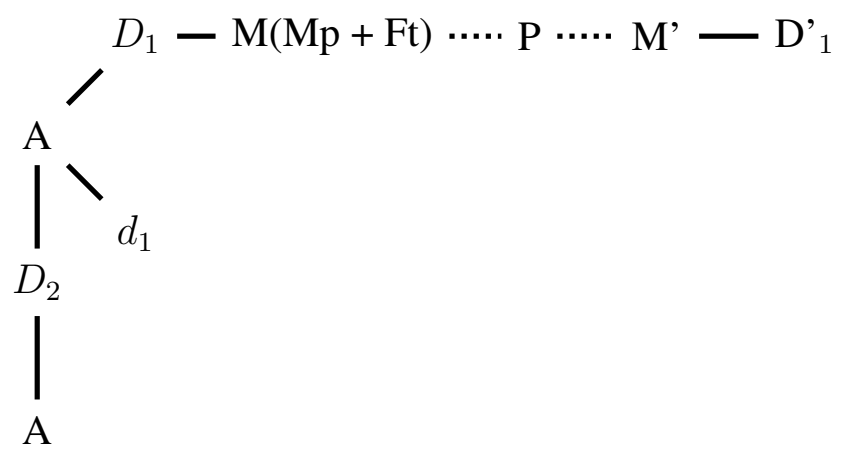

Onde:

$\mathrm{A}=$ ações; $\mathrm{D} 1$ = capital dinheiro $1 ; D_{1} \ldots P \ldots D_{1}^{\prime}=$ ciclo do capital industrial;

$d_{1}=$ lucro de fundador; $D_{2}=$ capital dinheiro $2 ; A-D_{2}-A=$ bolsa de valores.

O lucro de fundador $d_{1}$ proporcionará ganhos adicionais no momento de abertura de seu capital, bem como na emissão de novas ações, tornando-se assim, lucros adicionais. A venda de ações pode ser usada para a ampliação da produção, com consequente geração de mais-valia, pela via da transformação do capital dinheiro em capital produtivo e, ao mesmo tempo, estas ações, após a sua emissão primária, entrarão no processo especulativo dos movimentos nas bolsas de valores pela transformação em $D_{2}$.

Por esta aparente via dupla de multiplicação de riqueza, nos parece que o lucro de fundador guarda vínculos tanto na esfera real, produtiva, quanto na financeira, de base especulativa. Como seu pressuposto está relacionado à existência de uma taxa de lucro esperada superior à taxa de juros, há, portanto, certa ligação com a produção, conforme diz Hilferding ao afirmar que "o lucro de fundação ou emissão não é nem lucro, nem juro, mas lucro capitalizado de empresário. Seu pressuposto é a transformação de capital industrial [capital produtivo] em fictício" (ibid, p. 172).

Econômica-Niterói, v. 20, n. 2, p. 135-158. Dezembro, 2018 
Nessa criação de lucros adicionais proporcionados pela constituição e ampliação das sociedades anônimas em novos espaços econômicos, nos parece que Hilferding está sugerindo que o lucro de fundador também passa a ser uma nova fonte de acumulação que foi buscada, e continua sendo, como forma de expansão imperialista pelo mundo a partir da abertura e expansão das SA's no mercado acionista ${ }^{6}$. Suas conexões ultrapassam, portanto, as fronteiras da produção capitalista, já que os ganhos dos fundadores, com a transformação do capitalista em proprietário-acionista, funcionam também como nova forma de concentração e centralização da riqueza representada pela expansão do capital fictício nos territórios econômicos, sendo também um novo estímulo à expansão imperialista.

A intensificação dos processos de fusão e aquisição, por exemplo, num contexto de privatização de empresas estatais a partir dos anos 1970, trouxeram, a partir desses pressupostos deixados por Hilferding, novos elementos para a análise do capitalismo contemporâneo. Tais fenômenos que se intensificaram na última quadra do século XX e se avolumaram no limiar do atual podem ser entendidos como uma reestruturação do capital que reafirma uma tendência secular enunciada por nosso autor.

No âmbito das corporações, certas metamorfoses conduziram a um nível de financeirização delas que apresentaram as seguintes características ${ }^{7}$ : i) a conclusão mundial da descentralização produtiva nos termos do fordismo a partir de empresas norte-americanas, europeias e japonesas criou um elevado volume de remessas de lucros e dividendos que seriam cada vez mais reinvestido fora do circuito produtivo; ii) ao largo dos bancos centrais, as corporações passaram crescentemente a ter uma maior autonomia no financiamento de capital de giro e ampliação patrimonial por meio de transações financeiras, muitas delas nos termos de lucros diferenciais; iii) a financeirização das corporações lhes dotaram de maior flexibilidade e acessibilidade às formas de endividamento, inflando seus canais de lucratividade no âmbito global; iv) constituiu-se, assim, entre matrizes e filiais uma órbita de participação cruzada de investimentos em holdings com hedge em moedas conversíveis, que mesmo em espaços periféricos de alta instabilidade macroeconômica, os ganhos líquidos estiveram protegidos; v) ademais, as inovações financeiras se aliaram às inovações tecnológicas que permitiram uma flexibilização na forma de organização produtiva das corporações, permitindo-lhes deslocarem aquela antiga forma "multidivisional" para uma integração em cadeias produtivas que concentraram sua produção em "etapas mais nobres", quer dizer, mais vantajosas, do ponto de vista financeiro; vi) a reconcentração no gerenciamento do núcleo financeiro e tecnológico das corporações (core business), tercei-

\footnotetext{
${ }^{6}$ O Facebook, por exemplo, abriu seu capital na bolsa de valores em 2012 e, naquele momento, seus fundadores, principalmente seu proprietário principal, Mark Zuckerberg, com controle de 55,8\% das ações, foram os mais recompensados. Mais recentemente, no caso da compra do WhatsApp pelo Facebook, em fevereiro 2014, as indicações são de que a "aquisição do WhatsApp totalizou US\$ 19 bilhões, sendo US\$ 4 bilhões em dinheiro e US\$ 12 bilhões em ações da rede social. Além disso, o WhatsApp terá direito a mais US\$ 3 bilhões em "ações restritas" a serem distribuídas aos fundadores do aplicativo e seus funcionários ao longo de quatro anos a partir do fechamento do negócio”. (Disponível em: http://oglobo.globo.com/tecnologia/facebook-compra-whatsapp-por-us-19-bilhoes-11656044).

${ }^{7}$ Síntese a partir de Campos (2009).
} 
rizando ramos não estratégicos das cadeias produtivas, lhes guarneceram de maior controle e rentabilidade; vii) geograficamente, aquela forma de organização multidoméstica das corporações onde as filiais reproduziam na zona de destino, principalmente periférica, uma estrutura produtiva similar à matriz, respondendo por determinados impulsos de industrialização por substituição de importações em escala nacional, deu lugar a um novo subsistema afiliado que relativizaria as escalas nacionais intermediárias de desenvolvimento capitalista, priorizando a relação local-global, de modo a enfraquecer os sistemas econômicas nacionais maduros e aqueles em construção; viii) por fim, tal processo gestou nas corporações um poder de coordenação por meio de múltiplas operações nos circuitos financeiros intra-empresa (transferências líquidas) e extra-empresa (mercado de câmbio), e anexação de bancos, cuja direção financeira da holding passou a coordenar um esquema de valorização mais fictícia do capital financeiro, tendo entre os vários objetivos, a recentralização por meio de fusões e aquisições.

É de se destacar, portanto, que a intensificação da própria centralização do capital via política imperialista teve e continua tendo como eixo as grandes corporações. Assim, a abertura de sociedades anônimas em novos espaços econômicos contribui para proporcionar lucros de fundador.

A fim de compreender como a maturação desse processo de valorização do capital acionário se projeta ao exterior, precisamos classificar os tipos de exportação de capital. Para Brewer (1990, p. 100-101), distinguem-se três formas de exportação de capital em Hilferding: primeiramente, existem os movimentos de capitais para as partes subdesenvolvidas do território econômico, que funcionam como motivo de expansão dos espaços para obter novos domínios para investimentos. Em segundo lugar, existem os investimentos para as partes independentes do mundo, servindo como meio de integrar estas zonas ao território nacional ou criar um motivo para sua incorporação ulterior a fim de preservar seus investimentos; e finalmente, tem os investimentos sobre o território de outra nação.

Independente de qual seja o motivo, como já indicado anteriormente, a constante busca pela valorização do capital está no centro da análise. Se, conforme Corrêa (2012, p. 76), "a política imperialista do capital financeiro exigia, portanto, em primeiro lugar, a relação de subordinação das economias atrasadas com relação às mais desenvolvidas", sendo que este ponto "não foi muito aprofundado por Hilferding" (p. 76), a criação de mais-valia nos países subdesenvolvidos e sua transferência, via sociedades anônimas, para o centro do capitalismo, foi, e continua sendo, um marco na dinâmica imperialista tanto no período histórico vivido pelo autor quanto na fase atual do capitalismo contemporâneo, associando-se, cada vez mais, à sua dimensão financeira, sendo a forma do capital fictício a mais desenvolvida e mistificada neste aspecto. Se naquele momento a lógica da expansão financeira se concentrava no capital financeiro, com maior participação dos bancos, atualmente tal relação ganha novos contornos no capitalismo contemporâneo, como pela crescente participação dos investidores institucionais representada pelos fundos de pensão e de investimento e seguradoras que procuram novas fontes de acumulação tanto na

Econômica-Niterói, v. 20, n. 2, p. 135-158. Dezembro, 2018 
esfera produtiva quanto na especulação financeira.

O fato é que nestes novos espaços de acumulação, a exportação de capital amplia sua dimensão para além do capital produtivo, dando uma conotação que ultrapassa o próprio conceito de exportação de capital citado anteriormente. E nesse contexto, outra categoria descrita por Hilferding, os lucros diferenciais, nos ajuda a desvendar novos elementos que se incorporam à dinâmica das políticas imperialistas contemporâneas.

\subsection{Lucro Diferencial}

A partir do momento em que Hilferding nos sugere a interlocução entre a exportação de capital via trustes e cartéis, bem como a criação de lucros de fundador, nos parece que a sua noção de imperialismo se amplia ainda mais, saindo da mera relação com as sociedades anônimas para entrar nos movimentos financeiros dos proprietários-acionistas. Com isso, há uma articulação maior entre o movimento geral do capital, no âmbito da totalidade, com as partes representadas pelos proprietários acionistas. Esses receberão lucros que somente lhes cabe.

Mas, se a relação do capital acionário guarda certa ligação com a atividade produtiva, por outro lado outra categoria apresentada por Hilferding, e até o presente momento não identificada por nós em nenhum texto de autores que discutem o autor, acrescenta elementos importantes para se compreender os fenômenos financeiros do capitalismo contemporâneo. Estamos nos referindo aos lucros diferenciais.

De forma resumida, os lucros diferenciais de Hilferding referem-se aos ganhos advindos da compra e venda de papéis no jogo especulativo dos mercados financeiros. Para Hilferding (1985, p. 139),

os lucros ou prejuízos da especulação surgem, portanto, apenas das diferenças das valorizações correspondentes dos títulos de juro. Elas não são lucros, nem participação da mais-valia [grifo nosso], mas nascem tão-somente das oscilações das valorizações da participação da maisvalia que sai da empresa e cabe aos proprietários de ações, oscilações que, como ainda veremos, não precisam surgir da variação do lucro verdadeiramente realizado. São puro lucros diferenciais.

Suas palavras dão margem para uma interpretação que sugere o total descolamento das atividades financeiras, referindo-se mais precisamente sobre o capital acionário, sem a contrapartida direta da criação de valor e mais-valia ${ }^{8}$. De todas as formas, os lucros diferenciais encontram-se em um estágio ainda mais reificado das relações econômicas

\footnotetext{
${ }^{8}$ No capítulo XX de O capital financeiro, Hilferding contextualiza historicamente, de maneira mais clara, os lucros diferenciais ao se referir, por exemplo, sobre a especulação com as tulipas. Afirma: "Desapareceram irreparavelmente aquelas psicoses em massa que a especulação provocava no início da era capitalista, aqueles tempos felizes, quando cada especulador se sentia um deus que criava um mundo do nada. A burla do cultivador de tulipas com seu fundo idílico de paixão poética pelas flores, a burla dos
} 
entre o capital produtivo e o capital fictício, esse último especulativo por natureza. Certamente, em seu momento histórico, a importância e a magnitude dos lucros diferenciais eram infinitamente menores quando comparados à dinâmica especulativa da fase atual do capitalismo ${ }^{9}$.

O movimento dos lucros diferenciais está, dessa forma, centrado nos possíveis ganhos advindos das transações especulativas nos mercados financeiros. Em economias que remuneram esta fração do capital com altas taxas de juros, como nos países subdesenvolvidos, as consequências imediatas são sentidas a partir da intensificação da transferência de riqueza real da esfera produtiva para a financeira via remuneração do capital financeiro, e, também, pela criação de lucros diferenciais adquiridos das variações de preços dos ativos financeiros, ações e títulos por exemplo, no jogo especulativo dos mercados financeiros.

Partindo desses elementos, nos parece que os lucros diferenciais, que, a nosso ver, entrariam no percurso $\mathrm{A}-D_{2}-\mathrm{A}$ da figura 1 anterior, seriam mais um fator de busca incessante do capital por novas formas de acumulação, sobretudo na periferia do sistema. Forma essa contraditória é verdade, pois se a fonte da riqueza capitalista se baseia e se funda, a nosso ver, no domínio e na exploração da força de trabalho, esses lucros diferenciais são insustentáveis por natureza, no sentido de não permitirem uma reprodução ampliada do capital. Se ele proporciona ganhos financeiros para os especuladores, do ponto de vista individual, não possibilitam a reprodução capitalista do ciclo do capital industrial, D - M - D'. Nesse caso, seus tentáculos ultrapassariam o mero jogo do capital acionário, estudado por Hilferding, expandindo-se também para outras formas de capital fictício, como os títulos da dívida.

Sua autonomização ganhou contornos fetichistas mais complexos, estéreis, na essência, mas, com alto grau de valorização fictícia da riqueza, na aparência. Não é demais afirmar que tais ganhos individuais são reais, constituem uma unidade do real, não devendo, portanto, ser desconsiderados enquanto objeto de análise. Assim, essa forma de capital fictício se eleva a grau extremo de apropriação e criação de riqueza fictícia. Neste sentido, defendemos que as últimas décadas do século XX e as primeiras do século XXI, período marcado por crises capitalistas, trazem consigo elementos diferenciados que caracterizariam, junto ao capital fictício e os lucros diferenciais, novas formas de acumulação em

mares do sul com sua incitante fantasia aventureira de descobrimentos inauditos, os projetos de Law com suas intenções de conquista universal - tudo isso indica a caça aberta de lucro diferencial que encontra seu fim com a catástrofe financeira de 1873" (ibid, p. 276-277). Chancellor (2001, p. 35) diz que "na esteira da crise, a "tulipomania" deu lugar à "tulipofobia" - uma violenta reação contrária, análoga à aversão popular pelas ações ordinárias após o Grande Craque de 1929”.

${ }^{9}$ Sobre o crescimento dos ativos financeiros na atualidade, informações do McKinsey Global Institute indicam que o estoque dos ativos financeiros no mundo entre os anos 1980 a 2010 aumentaram, aproximadamente, 20 vezes, enquanto que o PIB mundial cresceu somente 6 vezes. Soma-se a isso, conforme Marques e Nakatani (2014, p. 148), que "o total de derivativos Over The Counter (OTC) que eram de US\$ 297,7 trilhões, em valor nocional, em 2005, salta para US\$ 632,6 trilhões em 2012, enquanto o PIB mundial foi de US\$ 45,7 trilhões, em 2005, e chegou a US\$ 71,7 trilhões, em 2012”.

Econômica-Niterói, v. 20, n. 2, p. 135-158. Dezembro, 2018 
novos espaços econômicos. Expressariam o último estágio do antagonismo de valorização que o capital financeiro de Hilferding pode projetar diante de seu desejo de valorização. Ou seja, oriunda da crescente socialização da produção, a autonomização financeira nega a base de valorização que lhe sustenta, exacerbando a concorrência entre capitais e a relação capital-trabalho, cujo sintoma dessa lógica capitalista só pode manifestar-se na forma de crise, que também pode lhe servir como indução para um novo ciclo de acumulação.

$\mathrm{O}$ crescimento atual do circuito financeiro, representado pelo fluxo de capitais ao longo das últimas décadas do século XX e início do XXI, esteve acompanhado pela liberalização das contas de capitais das balanças de pagamentos ao redor do mundo, permitindo assim a livre circulação de capitais especulativos entre os países. Ao mesmo tempo, as políticas econômicas adotadas no interior dos países mantiveram traços de flexibilização cambial, controle inflacionário pela restrição da demanda, restrição salarial, redução dos gastos sociais, elevados endividamento interno e externo das nações, provocando crescente vulnerabilidade externa sobretudo naquelas organicamente dependentes do capital internacional. A política cambial e de taxa de juros garantia e garante, ao mesmo tempo, remunerações fictícias para os investidores externos e internos na busca incessante pela valorização de seus ativos. As próprias SA's também passaram a se relacionar de forma mais direta ao processo de valorização de suas ações e títulos de dívida privada nas bolsas de valores, impulsionada e direcionada para a maior remuneração, via dividendos (e outros rendimentos), dos acionistas.

Como sabemos, estes e outros espaços especulativos aparecem no conjunto do próprio capital bancário que, em sua maior parte, é fictício, apresentando composição crescente mesmo após a eclosão da crise em 2008/09, o que tem provocado contração econômica, riscos e instabilidades frequentes na economia mundial. O BIS (2018, p. vii) afirma que

em alguns aspectos, estes riscos refletem o desequilíbrio da recuperação pós-crise e o fato de que se baseou excessivamente sobre a política monetária. Onde as fragilidades financeiras existem, elas são acumuladas, como habitualmente, de maneira progressiva e persistente. De forma geral, as valorizações dos mercados financeiros, como observado anteriormente, são excessivas, e o estoque mundial da dívida (pública e privada) em relação ao PIB teve uma alta contínua (nossa tradução).

A dívida mundial estimada pela instituição saiu de 200\% do PIB, em 2007, para, dez anos após, em fins de 2017, ultrapassar os 300\%, uma massa de títulos de dívida que reflete a dinâmica especulativa no capitalismo contemporâneo levando, segundo a própria instituição, ao fato de que "em conclusão, o caminho da normalização é um caminho estreito" (BIS, 2018, p. 44).

Assim, o capital fictício, pela via dívida pública, como categoria desenvolvida por Marx, assume fortemente sua forma de valorização. As estratégias de liberalização dos mercados financeiros ao longo das últimas décadas e os investimentos de portfólio, de 
caráter curto-prazista, bem como as compras e vendas das ações em mercados secundários, estão também associadas à busca pelos lucros diferenciais. Diferente de Brewer (1990, p. 102), e por consequência do próprio Hilferding, já que o primeiro se baseava nas indicações do último ao afirmar que

\begin{abstract}
o desenvolvimento do capital financeiro também mudou a forma de exportação de capital. Os países nas quais o capital financeiro não se desenvolveu (Inglaterra, França) exportava capital pelo investimento de portfólio, pela concessão de empréstimos e compra de ações das empresas estrangeiras. Onde o capital financeiro estava mais desenvolvido (Alemanha, Estados Unidos), a exportação de capital tende a assumir a forma de investimento direto nas empresas produtivas controladas a partir do país de exportação, garantindo que o exportador de capital tenha o maior controle,
\end{abstract}

o que se vê no atual momento histórico é, com muita intensidade, a exportação de capital por novos espaços econômicos a partir, sobretudo, da expansão do capital fictício. A conta de portfólio, da mesma forma que também o investimento direto estrangeiro, passou então a representar a externalização e crescimento dos ativos financeiros a partir do desenvolvimento do sistema de crédito e bancário facilitando, assim, os ganhos especulativos nas transações financeiras. Uma ligação de dupla face que possui, por um lado, uma crescente antítese entre os ganhos empresariais e a parcela de juros paga ao prestamista e, por outro, a exportação de capitais à procura de lucros diferenciais nos novos espaços de valorização representados pelos mercados financeiros especulativos de títulos e ações. A política imperialista via lucros diferenciais, passa, então, pelas próprias características históricas atuais, diferentes da de Hilferding, a se pautar pelos ganhos proporcionados pelas políticas de valorização do capital fictício que têm em seus fundamentos econômicos uma elevada remuneração aos seus proprietários.

A atual fase do capitalismo contemporâneo nos impele então a afirmar que, para além das vantagens de controle das SA's pelas compras dos títulos de propriedade, garantindo maior comando sobre as mesmas, conforme Hilferding indicava, o capitalismo também se alimenta, contraditoriamente, dos lucros diferenciais. E isso também deve ser incorporado como um novo padrão mundial de acumulação, ou de forma mais intensa, em novos espaços econômicos para a política imperialista. Os fluxos de capitais que se movimentaram nas contas de portfólio das balanças de pagamentos das diversas economias do mundo a partir dos anos 1970, período inicial de desregulamentação financeira, são sugestivos para se entender esta dinâmica especulativa.

Dados do Banco Mundial ${ }^{10}$ sinalizam que, no mundo, a entrada líquida de investimentos em carteira, em dólares correntes, foi de 1,3 bilhão em 1970, aumentando, já no contexto do início da abertura econômica em países capitalistas centrais, como Inglaterra e França, para 15,5 bilhões em 1980. Daí para frente, o processo de expansão se

\footnotetext{
${ }^{10}$ Fonte: Fundo Monetário Internacional, Balanço de pagamentos database, e Banco Mundial, Estatísticas de Dívida Internacional. Disponível em: <https://data.worldbank.org/indicator/BX.PEF.TOTL.CD.WD>.
}

Econômica-Niterói, v. 20, n. 2, p. 135-158. Dezembro, 2018 
intensificou com o próprio avanço das desregulamentações financeiras para as regiões periféricas da economia mundial. A partir dos anos 1990, a escalada foi determinante: 85,6 bilhões em 1991, 647,4 bilhões em 2000, 801,3 bilhões em 2010 e 1,2 trilhões de dólares em 2017, indicando, em termos absolutos, o peso progressivo das transações financeiras. Não coincidentemente, tais movimentos crescentes acompanharam a eclosão de crises financeiras, como manifestação de crises capitalistas, tanto na periferia quanto no centro do capitalismo mundial.

A partir destes elementos, as indicações de Hilferding nos fornecem subsídios para acrescentar ao debate o fato de que nas novas políticas de avanço imperialista, pela via dos lucros de fundador e lucros diferenciais, as estratégias do capital ultrapassam as fronteiras econômicas territoriais e se materializam e desmaterializam sob formas cada vez mais mistificadas de expropriação. A natureza dialética do capital se manifesta, assim, por caminhos diferenciados, mas mantém a contradição fundamental entre produção social e apropriação privada da riqueza.

\subsection{Empréstimos, Investimentos Direto Estrangeiro (IDE) e Portfólio}

Ao discutirmos outras formas possíveis de exportação de capital é necessário frisar que elas não são estanques em suas distintas funções, pelo contrário, carregam consigo a articulação imperialista que emana do capital financeiro. Trata-se então de entender as diferentes formas de extroversão de capital sem anular o nexo que a valorização exprime por diversos espaços e maneiras de explorar trabalhadores, reforçando o conceito de capital financeiro. Daí a necessidade de Hilferding em conceber a exportação de capital como um cruzamento de variados modos de difundir extração de valor as quais se retroalimentam e se complementam na unidade do capital financeiro.

As formas de exportação de capital mais próximas da atividade industrial, ou seja, empréstimos e IDE são, portanto, indissociáveis daquelas que se aproximam do capital fictício como vimos pelos lucros de fundador. Essa unidade também se estabelece justamente pela crescente socialização do capital em detrimento da apropriação de valor gerado pela classe trabalhadora. A valorização capitalista em seu maior nível de reificação não elimina, pelo contrário, fortalece e potencializa a capacidade de exportar capitais com o intuito de conservar a acumulação ampliada. Por sua vez, o encadeamento que resulta essa potencialidade e que a projeta no espaço econômico internacional não significa menos concorrência capitalista, mas uma mudança de qualidade segundo Hilferding, uma vez que não são mais capitais individuais atuando em um espaço de livre-comércio, mas enormes blocos de capitais socializados e blindados pelos protecionismos que se chocam mutuamente.

Especificamente, as transações "casadas" de exportação de capital têm como objetivo atender os seguintes requisitos: i) remunerar os juros de empréstimo; ii) realizar as remessas de lucros e dividendos dos investimentos diretos e de portfólio, respectivamente; iii) 
viabilizar a exportações de mercadorias, sobretudo, manufaturados; iv) garantir o fornecimento de alimentos para rebaixar custos de reprodução da força de trabalho e de matérias primas que alimentam a expansão industrial. A maneira pela qual essas diferentes formas de extração de valor se cruzam depende das características históricas dos países emissores e de seu grau de desenvolvimento capitalista, bem como do vínculo com o território destinatário.

A diferenciação no desenvolvimento capitalista nacional encontra na extroversão do capital uma via de unificação que promove a modernização industrial e a possibilidade de exportação não apenas de seu montante acumulado líquido, mas da própria estrutura industrial em forma de IDE. Essa transição não é linear, tampouco, exclusiva dos capitalismos mais modernos.

No entanto, a especificidade histórica que altera a própria natureza do IDE a partir da Segunda Revolução Industrial se refere à sua origem resultante do aparecimento da industrialização pesada, cuja característica central foi sua composição monopolista e financeira. Se num primeiro momento isso representou uma força unificadora desses capitais, principalmente entre empréstimo e IDE desenvolvendo algumas zonas tardias do capitalismo, em outro, traduziu-se por uma expansão monopolista que acirrou a concorrência intercapitalista. Além da possibilidade de difusão do desenvolvimento das forças produtivas em regiões periféricas, a conquista de novas áreas para expansão industrial denotaria a exportação de novas formas de controle sobre elas, aguçando a concorrência entre capitais e o conflito capital-trabalho.

Como ilustração a partir de Andreff (2000), é possível entender a dinâmica do estoque mundial do IDE durante o século XX se comparamos as economias centrais com as periféricas. O estoque de IDE em 1914 era de US\$14,3 bilhões, sendo que o Reino Unido participava em $45,5 \%$ da sua origem, EUA $(18,5 \%)$, Japão $(0,1 \%)$, Alemanha $(10,5 \%)$, França $(12,2 \%)$, outros desenvolvidos $(13,2 \%)$ e periferia $(0,0 \%)$; sendo que o destino para 1914 era de 37,2\% para os países desenvolvidos e de 62,8\% para os países subdesenvolvidos. Ao passo que o estoque mundial de IDE em 1960, quando o papel das corporações norte-americanas eram fundamentais sobre o Ocidente capitalista, era de US\$ 63,1 bilhões, sendo que o Reino Unido participava em 17,1\% da sua origem, EUA (52\%), Japão $(0,8 \%)$, Alemanha $(1,3 \%)$, França $(6,5 \%)$, outros desenvolvidos $(21,2 \%)$ e periferia (1,1\%); o destino para 1960 era de 67,3\% para os países desenvolvidos e 32,7\% para os países subdesenvolvidos. Já o estoque de IDE em 1991, que já refletia a tendência crescente de exportação de capital asiático desde os anos 1970, começando com Japão, depois Coreia do Sul, e, mais recentemente, China, era de US\$1.799 bilhões, sendo que o Reino Unido participava em 13,6\% da sua origem, EUA (24,3\%), Japão (13,1\%), Alemanha $(9,4 \%)$, França $(7,4 \%)$, outros desenvolvidos $(28,3 \%)$ e periferia $(3,9 \%)$; reflexo do IDE cruzado nas economias centrais desde os anos 1980, o destino para 1991 era de 80,1\% para os países desenvolvidos e de 19,9\% para os países subdesenvolvidos.

Distante de representar um "concerto de nações", a unidade do capital financeiro ex- 
primida por Hilferding refere-se ao desenvolvimento alemão e norte-americano como prenhes de uma lógica eminentemente imperialista, cuja concorrência econômica se revelaria por domínios políticos globais. A rivalidade imperialista também se projetaria nos espaços periféricos, fazendo das regiões "pré-capitalistas" economias potenciais para alavancar o capital financeiro em sua valorização internacional. $\mathrm{O}$ entrelaçamento de diferentes formas de exportação de capital se reproduziria em tais espaços. Nessa conjuntura era comum empreendimentos industriais alemães que resultavam de empréstimos de bancos ingleses ou franceses para investimentos em áreas secundárias como o Leste Europeu ou a América Latina, exigindo destes a importação de suas mercadorias e a exclusividade no fornecimento de alimentos e matérias-primas.

Nessa época em que Hilferding está analisando, o IDE de bens de consumo duráveis não é dominante como seria em algumas décadas adiante. Ao final do século XIX, como ele próprio aponta, o IDE está concentrado em setores primários para extração de matérias-primas e na infra-estrutura urbana, de transportes, e portuária para exportação de commodities. Mesmo assim, o novo poder que nasce do IDE extrapola o período vigente, pois estabelece um controle diferenciado no capital internacional da Segunda Revolução Industrial, tornando-se um bem inalienável da internacionalização do capital e igualmente definidor das estratégias futuras de valorização das corporações transnacionais.

Nessa época em que Hilferding está analisando, o IDE de bens de consumo duráveis não é dominante como seria em algumas décadas adiante. Ao final do século XIX, como ele próprio aponta, o IDE está concentrado em setores primários para extração de matérias-primas e na infra-estrutura urbana, de transportes, e portuária para exportação de commodities. Mesmo assim, o novo poder que nasce do IDE extrapola o período vigente, pois estabelece um controle diferenciado no capital internacional da Segunda Revolução Industrial, tornando-se um bem inalienável da internacionalização do capital e igualmente definidor das estratégias futuras de valorização das corporações transnacionais.

Em síntese, Hilferding nos mostra como o padrão de internacionalização nesse momento concentra o controle financeiro não apenas na mobilização de capitais que podem ser exportados, mas na própria subordinação dos importadores ao raio de manobra imperialista que as economias de vanguarda impõem. Em um primeiro estágio de desenvolvimento do capital internacional foi possível promover o sistema de transporte e certas indústrias dos países atrasados (geralmente da Inglaterra, Bélgica e França para Alemanha e EUA), o que permitia alavancar a industrialização dessas economias tardias de forma a emancipá-las da dependência externa.

Em um segundo momento, entretanto, a própria exportação de capital internacional das economias alemãs e norte-americanas exerceu um controle maior sobre as novas regiões importadoras, cuja independência econômica similar seria interditada pelo capital monopolista. A estrutura protecionista que impulsionaria o capital internacional a partir dessa fase seria a mesma que dotava seus Estados nacionais de poder suficiente para obstruir o fortalecimento de outras regiões, mesmo quando essas desejavam reproduzir o 
estilo dos exportadores originais como Hilferding (1985, p. 306) nos mostra:

Assim, também nessa relação, o sistema de cartéis e trustes, forçando a exportação de capital, concede aos capitalistas dos países onde a monopolização da indústria é mais avançada uma vantagem com relação aos países com indústria menos organizada, e desperta dessa forma nesses países a vontade de acelerar a cartelização da indústria própria através do protecionismo, enquanto reforça nos países mais avançados a vontade de assegurar, a todo custo, a continuidade da exportação de capital, mediante a exclusão de toda concorrência do capital estrangeiro.

Outra contribuição de Hilferding que se aplica à atualidade é que o desenvolvimento do IDE em diferentes formas possíveis de internacionalização produtiva, não implica um divórcio com as formas mais líquidas. Pelo contrário, a expansão das corporações das economias centrais no século XX da mesma forma que criou novas estruturas produtivas sem descentralizar o controle tecnológico e financeiro, desenvolveu íntimas relações com bancos que redundaram no surgimento, por exemplo, do Euromercado nos anos 1960 forçando a liberalização financeira em décadas posteriores ${ }^{11}$.

Para Hilferding, além da relação de empresas e bancos que permitem transações casadas entre investimentos diretos e empréstimos, o caráter especulativo que nasce dessa relação se associa ao investimento de portfólio como um lócus estratégico para valorização. Como vimos anteriormente, o mercado acionário, impulsionado pelos ganhos com o lucro de fundador e os lucros diferenciais, revela como os rendimentos e suas reaplicações vão se distanciando do capital produtivo. Ao assumir a capitalização em uma taxa de juros corrente, o capital fictício produz um elevado nível de autonomização que aparece como a negação da base de valorização que lhe sustenta. O "capital acionário" se torna a principal expressão do capital fictício. Mesmo essa sendo a forma mais fetichizada, específica do padrão mundial de acumulação capitalista que Hilferding está investigando, aqui também podemos aludir que a sua contribuição ultrapassa seu tempo.

Embora o autor não tenha explicitado a exportação de capital na forma de investimentos de portfólio como fez para o IDE, sua fundamentação acerca do capital fictício em lucro de fundador e lucros diferenciais mostra como a especulação reflete tanto o desenvolvimento do capital financeiro em suas múltiplas contradições, quanto a necessidade de superação delas por meio da extroversão. Assim como os investimentos produtivos exercem um controle, principalmente nas economias periféricas, os investimentos de portfólio também terão esse poder, exportando a própria contradição do capital em sua forma mais reificada.

Interessante que novamente Hilferding segue os passos de Marx e Engels. Ao investigar a difícil conjuntura chinesa da "Guerra do Ópio" (1839-1842), Marx (1984) constatou

\footnotetext{
${ }^{11}$ Furtado (1982) evidenciou a unidade entre os interesses de valorização das corporações transnacionais e o sistema internacional bancário em praças off-shore nos anos 1970, bem como suas implicações para as industrializações periféricas.
}

Econômica-Niterói, v. 20, n. 2, p. 135-158. Dezembro, 2018 
que o controle inglês por meio do comércio e dos investimentos produtivos nessa região, passando pelas campanhas militares, também estabelecia um canal por onde se projetava a especulação das letras de câmbio e emissão de ações, atreladas à crescente oferta creditícia do mercado financeiro londrino. Marx e Engels apontaram desse modo como a especulação podia se tornar um instrumento que retroalimentava os negócios da metrópole fincando vínculos neocoloniais em novos esquemas produtivos e fictícios de valorização do capital.

Utilizando do exemplo de implantação de usinas hidrelétricas, Hilferding igualmente faz questão de explicitar a ligação entre bancos e empresas na fundação de SA's em economias periféricas, onde se abre um espaço potencial de valorização fictícia. Com isso ele exprimiu com exatidão a mutabilidade dos negócios bancários em investimentos industriais. Até aí a relação com o capital fictício não se explicita, mas uma vez criada a SA, de imediato temos o lucro de fundador que pode converter-se em reinvestimentos em capital produtivo e assim viabilizar a drenagem de mais-valia do exterior. A outra opção, todavia, é o circuito A - D2 - A que acelera a troca de papéis na Bolsa de Valores produzindo lucros diferenciais, e assim desenvolver mercados secundários. Nesse caso, a exportação de capital ainda que seja estimulada por uma atividade produtiva no exterior, se transfigura em investimentos de portfólio no centro do sistema, fortalecendo a valorização do capital fictício. Trata-se na verdade de uma nova etapa de capitalização por meio de multiplicação de "transações rendosas" (HILFERDING, 1985, p. 195) via troca de ações, novas emissões e subscrições, apresentando "lucros incrementados" (idem).

Hilferding deixa claro que em todo esse processo libera energia suficiente que resulta em "forte motivo para exportação de capital industrial" (HILFERDING, 1985, p. 305). No entanto, o que em sua época não permitiu ele prever, foi como que dessa dinâmica do capital financeiro é possível dilatar a própria órbita da especulação de espaços econômicos centrais para periféricos, viabilizada por nexos imperialistas que se definem a cada conjuntura histórica. Melhor dizendo, os lucros diferenciais, ou seja, a valorização sem vínculo produtivo, donde se alcança, atualmente, um estágio de autonomização do capital fictício jamais visto, também se substancia em novas fronteiras para exportação de capital.

Tal paroxismo, impossível de ser capitado por nosso autor, é característico do momento atual, cujo padrão mundial de acumulação assume elevadíssimo grau de financeirização. Os investimentos de portfólio (ações, títulos públicos, funds, securities, options, swaps, etc.) encarnam a dinâmica contemporânea do capital financeiro, em que a especulação, como negação máxima do valor real, da mesma forma que se metamorfoseia por inúmeros modos de valorizações fictícias capazes de contra-restar por algum tempo a tendência à queda na taxa de lucros, produz exponencialmente as contradições que solapam as bases de reprodução ampliada do capital, se desvelando em crises capitalistas cada vez mais severas, tal como foi a de 2008 e que prossegue até os dias atuais com previsões de baixo nível de atividade e crescimento econômico, bem como de aumento nas desigualdades sociais. O FMI (2018, p. vi) afirma que "as projeções de crescimento foram 
revisadas para baixo na zona Euro e no Reino Unido, uma vez que a atividade foi menos dinâmica do que a prevista no início de 2018", reproduzindo uma dinâmica instável e, em boa parte, sem fundamento de criação de riqueza real.

Parte de tal dinâmica se assenta no livre trânsito do investimento de portfólio nas diferentes praças de zona de expansão imperialista. E é imperialismo, sobretudo, porque no contexto atual se impõe um controle transnacional sobre as políticas econômicas, principalmente dos países periféricos, que objetivam garantir a mobilidade do capital, neutralizando a capacidade nacional de definir uma política monetária própria, um determinado regime de câmbio e uma maior autonomia sobre o orçamento público.

A especulação acionária e o investimento em renda fixa conduzidos pelo capital internacional, ainda que não gere valor nos termos do IDE como interpretados por Hilferding, consiste em sua essência no mesmo domínio imperial, pois arregimenta um controle do capital monopolista que subordina as políticas econômicas dos países hospedeiros às suas necessidades de valorização. No limite, à medida que se sacramenta a conversibilidade na conta financeira do balanço de pagamentos e remuneração real por meio de elevadas taxas de juros, fortalece-se o canal de extração de renda da periferia para as economias centrais, dimensionado, aliás, por um arco de interesses entre burguesias locais e internacionais.

Portanto, mesmo que esse processo atual de financeirização não possa ser totalmente decifrado pela leitura de Hilferding, são importantíssimos seus subsídios para entendermos a valorização do capital global cada vez mais preso à lógica do capital fictício, em que a diferenciação dos lucros de fundação e os lucros diferenciais exprimem a sua autonomização originada da própria dinâmica da circulação do capital. Aquilo que era apenas incipiente no final do século XIX torna-se dominante na atualidade, bem como um dos principais pressupostos dos nexos imperialistas que se renovam mantendo as velhas contradições. A rigor, se nos dias que correm está cada vez mais difícil compreender o capitalismo separando suas formas de extração e realização de valor que se enfeixam por diversos tipos de exportação de capital (empréstimos, IDE e portfólio) ${ }^{12}$, isso se deve à reprodução de uma totalidade do capital financeiro que nasceu no final do século XIX e

\footnotetext{
${ }^{12} \mathrm{O}$ próprio efeito "gravata borboleta" das corporações que operam atualmente representa tal complexidade. Segundo o estudo de Vitali et. al. (2011) numa amostra de 43 mil empresas de um universo de 30 milhões em 48 países de acordo com a definição da OCDE (Orbis de 2007), com o objetivo de analisar o rendimento operacional e o valor econômico das corporações, constataram-se que $75 \%$ do núcleo dessas empresas controlam elas próprias (participações cruzadas, umas controlando a propriedade das outras). Dessas 43 mil, um soma pequena controla $80 \%$ de suas operações, ou seja, 737 empresas transnacionais têm o network control de toda a rede corporativa mundial (12 vezes de controle em relação à riqueza que possuem, sendo que $75 \%$ desses atores são intermediários financeiros). Outro dado interessante dessa pesquisa é que $40 \%$ do controle sobre o valor econômico das corporações transnacionais estão nas mãos de um grupo de 147 do núcleo, ou seja, são "super entidades" na rede global das corporações. Em resumo, $1 \%$ das corporações transnacionais consegue controlar $40 \%$ de toda a rede, a maioria são instituições financeiras como: Barclays Bank, J.P. Morgan Chase \& Co e Goldman Sachs. Sendo que a maioria desses atores é de origem norte-americana e européia. Maiores subsídios à interpretação dessa pesquisa podem ser encontrados em Dowbor (2012).
}

Econômica-Niterói, v. 20, n. 2, p. 135-158. Dezembro, 2018 
que Hilferding soube abstrair a partir das formas concretas de seu contexto ${ }^{13}$.

\section{Exportação de Capital e Imperialismo}

Ao observarmos como o desenvolvimento do capital financeiro resultou em sua própria exportação, desdobrando-se em diferentes tipos que alterariam a anatomia da reprodução ampliada de capital, é chegado o momento de entendermos como a articulação imperialista sustenta e dá organicidade a esse processo. Para Hilferding a exportação de capital só é viabilizada pelo domínio imperialista, cuja força transforma-se numa alavanca do capital financeiro em suas variadas formas espaciais de valorização. O surgimento do capital financeiro e sua necessidade intrínseca de extroversão garantem o movimento de concentração e centralização do capital recriando os canais necessários para sua valorização. Ademais, a contribuição desse autor se deve a possibilidade de assimilar o capital financeiro em seu sentido universal refletido na reprodução conjunta de unidade, mobilidade e antagonismo. O domínio imperialista constitui a própria junção desses elos agindo de forma sincrônica na valorização capitalista, assim como diacronicamente incide sobre as diferentes contradições históricas que se manifestam em cada padrão mundial de acumulação.

Começando pela unidade, torna-se importante entendê-la como reflexo da socialização da produção, que ao arregimentar capitais individuais em uma mesma esfera de valorização, centraliza o controle de diferentes formas de capitais. Aqui há uma clara derivação do que Marx (1984) mostrou sobre a formação da sociedade anônima, cuja institucionalidade representaria o estágio máximo de socialização dos meios de produção e das forças de trabalho ("capital de indivíduos diretamente associados"), de forma a "abolir" a dimensão privada capitalista: "é abolição do capital como propriedade privada, dentro dos limites do próprio modo de produção capitalista" (MARX, 1984, p. 332). Essas transformações fazem com que o "capitalista funcionante" (empresário) se converta em administrador de capital alheio, ao passo que os proprietários de capital se transformam em meros proprietários, simples capitalistas monetários, no sentido genérico.

De Marx, Hilferding igualmente assimilou a virtuosidade que isso acarretaria para a acumulação capitalista. As sociedades anônimas se apresentam como o elemento-chave pelo qual se associa capital bancário com capital produtivo para ampliar os negócios numa escala jamais vista. A Bolsa de Valores seria uma espécie de catalisador que amplifica exponencialmente as possibilidades de valorização capitalista. Como vimos no item an-

\footnotetext{
${ }^{13}$ Scherer (1999, p. 82) problematizou essa questão para a atualidade da seguinte forma: "a análise do investimento multinacional e a da finança internacional são geralmente realizadas de modo estanque, dificultando a percepção de que o aumento no fluxo do investimento direto estrangeiro (IDE), principal instrumento de internacionalização das atividades das empresas multinacionais, se encontra estreitamente relacionado ao novo papel desempenhado pela finança no contexto econômico internacional, a partir de sua liberalização".
} 
terior, no caso do lucro de fundador, é na concentração da propriedade, independente da magnitude industrial, que se forja uma potência de valorização definidora do capitalismo que conhecemos. Hilferding (cap.VII, 1985) evidencia que o lucro de fundador longe de manter uma renda anual e fracionada, concentra enormes capacidades financeiras capazes de integrar novos capitais na forma-dinheiro. Daí a necessidade da própria Bolsa ser grande o suficiente para abrigar um jogo de "poderosos apostadores" e não de pequenos burgueses presos a "bolsas provinciais". Em síntese, esse processo cria as bases sobre as quais edificam os meios de centralização do capital que Marx havia apontado, uma vez que a sociedade por ações se coloca por um lado como um móvel estratégico para os bancos promoverem a monopolização. Grande parte do lucro de fundador pode ser utilizada para forçar, com preços elevados, a venda daquelas empresas destinadas a fortalecer cartéis, e mesmo trustes. Por outro lado, a própria indústria passa a ser "acionada por um capital que é muito maior do que o capital global de propriedade dos capitalistas industriais" (HILFERDING, 1985, p. 218).

A multiplicação de opções de investimento que o capital financeiro coloca nas mãos da classe dominante permite uma articulação inédita de seus interesses e um domínio de espaços nacionais numa nova configuração da riqueza, uma vez que

\begin{abstract}
pela separação entre a função da propriedade e a direção da produção, como a supõe o sistema de ações, surge a possibilidade e - com a intensificação da renda, por um lado, e o aumento do lucro industrial extra, por outro - a concretização de uma solidarização dos interesses de propriedade. A 'riqueza' não é mais diferenciada segundo suas fontes de rendimento e segundo sua origem do lucro ou do rendimento, mas aflui agora da participação em todas as porções em que se divide a mais-valia produzida pela classe operária (HILFERDING, 1985, p. 321).
\end{abstract}

Eclode assim uma extraordinária estrutura de exploração capitalista, que ao se desvencilhar de formas pretéritas de organização - tais como: indústrias familiares organizadas em uma única figura do proprietário e do gestor, ou mesmo inúmeras Bolsas provinciais incapazes de concentrar a riqueza para valorizar além de sua circunscrição, - delineia a fisionomia do que será o moderno capitalismo. A força aglutinadora do capital financeiro recoloca as classes dominantes numa posição de superação do liberalismo do capitalismo originário, ao tornar o protecionismo a forma dominante do desenvolvimento industrial.

O capital financeiro seria a intersecção das diferentes frações de classes, pois mesmo com distintos tempos históricos e origens, ele soldaria suas bases, projetando-as internacionalmente. Sem eliminar as disputas intercapitalistas, o capital financeiro permitiria arregimentar as grandes burguesias numa nova esfera de valorização, na qual a centralização do capital refletiria o curso que os diferentes padrões mundiais de acumulação assumiriam no futuro.

Da mesma forma, sedimenta-se a indiferenciação entre o caráter "especulativo" e "produtivo" da reprodução ampliada do capital. Obviamente que isso não altera a legalidade do capital que tem a real geração de valor em sua forma industrial, sendo suas

Econômica-Niterói, v. 20, n. 2, p. 135-158. Dezembro, 2018 
metamorfoses na esfera da circulação apenas formais. Não obstante, nascem aqui os meios pelos quais o capital pode exercer livremente sua mobilidade percorrendo caminhos de valorização por diferentes atalhos, em distintos níveis, tais como vimos no lucro de fundador e no lucro diferencial. Pela reflexão de Hilferding é possível dessa maneira entender como o objetivo máximo do capital financeiro é sempre a valorização, sendo garantida tanto por sua unidade quanto por sua mobilidade.

A questão da mobilidade do capital em Hilferding, ainda que deva ser vista com cautela, porque sua preocupação maior residia na "mobilização" de capitais na sociedade por ações, e delimitada às situações características do final do século XIX, não deixa de indicar, como afirmou Pinto (1994), a trajetória pela qual a "financeirização" moderna iria tomar. Ao mostrar como o capital financeiro impôs uma cisão entre a propriedade do capital e os meios de produção, Hilferding integra as partes que compõem a dinâmica do capital financeiro, revelando que para agirem livremente necessitam de crescentes graus de flexibilidade, mutabilidade e permeabilidade, resultado da sua "liquefação" ${ }^{14}$. E aqui se imprime o movimento de busca incessante do capital financeiro por formas cada vez mais reificadas de valorização, até chegar ao paroxismo de reproduzir autonomizando-se em relação à própria base produtiva que lhe sustenta, assumindo como vimos via lucro diferencial. Trata-se na verdade do último destino das contradições que percorrem o capital financeiro em sua ilimitada socialização da produção nos termos em que Marx (1984) percebeu nas sociedades anônimas. O resultado de tal desfecho não pode ser outro que não uma crise, uma crise na qual se revela o sentido profundo da fase monopolista do capital.

No afã de perseguir unidade e mobilidade indefinidamente, a própria reprodução do capital financeiro atrofia as bases de valorização circunscritas ao espaço econômico de origem, cuja resposta a esse limite estrutural passa necessariamente pela sua dilatação. À medida que se intensificam a socialização da produção e a apropriação privada da valorização, as contradições se ampliam no mesmo ritmo, sendo que o estreitamento dos canais de rentabilidade coloca a exportação de capital como um imperativo para superar as crises

\footnotetext{
${ }^{14}$ Esse conceito foi definido por Pinto (1994, p. 2) nos seguintes termos: "a característica inovadora do capitalismo financeiro (por oposição ao capitalismo industrial) não reside no critério do cálculo empresarial mas na velocidade e na amplitude com que estas estimativas são formuladas e difundidas. À medida que se multiplica o volume de recursos produtivos organizados sob forma de sociedade de ações, estende-se o raio de ação de riqueza privada líquida, cuja agilidade é uma decorrência de sua flexibilidade. Mais ainda, subordinam-se esferas de valorização que antes podiam se defender, por prazos ou menos prolongados, aos ditames impostos pela tendência à equiparação da taxa de lucro". Pinto, ao defender essa interpretação do conceito de capital financeiro de Hilferding, aplica-o para atualidade: "o que se alterou no capitalismo financeiro não foram os critérios de avaliação dos ativos mas a sua conexão com o processo de expansão real do capital. A interposição de um novo elemento entre o capitalista e os meios de produção (seja um depósito bancário ou um título acionário) expandiu o capital financeiro (fictício) a ponto de transformálo no veículo dominante da acumulação privada de riqueza. Os haveres produtivos foram gradualmente excluídos das carteiras de investimento privado sem no entanto perder o seu caráter capitalista, isto é, sua subordinação a uma relação social na qual os meios produção (são) monopolizados por determinada parte da sociedade" (PINTO, 1997, p. 22)
} 
que daí decorre, revelando a essência do modo de produção capitalista.

De fato, a exportação de capital não se refere apenas a "exportação de capitais", mas a própria exportação da relação social capitalista em uma lógica intrinsecamente imperialista, cuja função é preservar os vínculos mundiais que canalizam a valorização do capital financeiro. O imperialismo exprime desse modo uma política de dominação que assegura permanentemente o desenvolvimento das forças produtivas e da reprodução das relações tipicamente capitalistas delimitadas por um espaço mundial de acumulação, composto hierarquicamente por economias desenvolvidas e subdesenvolvidas.

\title{
4 Conclusão
}

Ao apresentamos os principais determinantes que condicionam o funcionamento do capital financeiro e as implicações de sua expansão via reprodução ampliada do capital, buscamos construir os pressupostos de Hilferding sobre a articulação imperialista. Com isso, estabelecemos as formas pelas quais substanciam a exportação de capital, desde as mais reificadas, como os lucros diferenciais, lucro de fundador, investimento de portfólio, até os empréstimos e investimentos diretos, sempre sustentando uma coesão entre elas. Também mostramos como o desenvolvimento do capital financeiro, e suas contradições criadas na órbita das diferentes formas de exportação de capital, engendram um determinado nexo imperialista, que se compõem historicamente pela unidade, mobilidade e antagonismo.

Mais que um esforço de apreender as categorias essenciais de Hilferding, bem como seu entendimento do contexto histórico da época, buscamos atualizar o instrumental deste autor caracterizando alguns elementos-chave que se originam dessa fase monopolista do capitalismo. Com isso, cotejamos, ainda que preliminarmente, os possíveis elos universais que associam parte do legado de Hilferding à complexidade atual da financeirização e de sua manifestação imperialista.

\begin{abstract}
The aim of this paper is to show how the relationship defined by Hilferding between the finance capital and the export of capital settles the imperialist nexus that gives meaning to the genesis of modern capitalism and its future projection, including the dependency ratio between the countries of the center and the periphey. To do so, we will identify the forms of capital export from the dynamic reproduction of finance capital, besides presenting the essential links that make up the imperialist joint between the finance capital in its historical emergence and its internationalization in the form of capital export. We have established export capital forms such as differential and founder profits, portfolio investment, loans and foreign direct investments, updating an instrumental characteristic of the monopoly phase of capitalism. Finally, we indicate possible links that link part of Hilferding's ideas to the current complexity of financialization and its imperialist manifestation.
\end{abstract}

Econômica-Niterói, v. 20, n. 2, p. 135-158. Dezembro, 2018 
Keywords: Hilferding, finance capital, export of capital, imperialism.

JEL: B1; G00; N2

\section{Referências bibliográficas}

ANDREFF, W. As multinacionais globais. [S.1.]: Bauru - SP: EDUSC, 2000.

BIS (Banque des Règlements Internationaux). [S.1.]: Rapport économique annuel, 2018. $<$ https://www.bis.org/publ/arpdf/ar2018_fr.htm>.

BREWER, A. Marxist theories of imperialism: a critical survey. 2. ed. [S.1.]: Routledge, 2000 .

BROWN, M. B. A economia política do imperialismo. [S.1.]: Zahar Río de Janeiro, 1978.

BUKHARIN, N. Imperialism and world economy. [S.l.]: São Paulo: Nova Cultural, 1984.

CAMPOS, F. A. d. et al. A arte da conquista: o capital internacional no desenvolvimento capitalista brasileiro (1951-1992). [sn], 2009.

CHANCELLOR, E. Salve-se quem puder: uma história da especulação financeira. [S.1.]: Editora Companhia das Letras, 2001.

CORREA, H. F. d. S. Teorias do imperialismo no século XXI:(in) adequações do debate no marxismo. Tese (Doutorado) — Tese de doutorado em Economia. Universidade Federal Fluminense, 2012.

DOWBOR, L. A rede do poder corporativo mundial. São Paulo, 2012. Disponível em: $<$ http://dowbor.org/2012/02/a-rede-do-poder-corporativo-mundial-7.html/>.

FRANCO, T. F. Imperialismo capitalista em três atos: investigações sobre o capitalismo. Campinas (SP), dissertação de mestrado, IE-Unicamp, 2011.

FURTADO, C. A nova dependência: dívida externa e monetarismo. [S.1.]: Paz e Terra Rio de Janeiro, 1983.

HILFERDING, R. O Capital financeiro. [S.1.]: Nova Cultural: col. Economistas, Sao Paulo, 1910.

HILFERDING, R. Le capital financier. [S.1.]: Paris, Editions de Minuit, 1970. 
PINTO, N. P. O Capital financeiro na economia contemporânea: uma revisão teórica e histórica de seu papel no desenvolvimento recente dos Estados Unidos. Tese (Doutorado) — Tese de doutorado em Economia. UNICAMP, 1994.

SABADINI, M. d. S. O capital fictício e suas formas: lucros de fundador, diferencial e fictício. In: GOMES, H. (Ed.). Especulacão e lucros fictícios: formas parasitárias da acumulacão contemporânea. São Paulo: Outras Expressões, 2015. p. 161-204.

SCHERER, A. L. F. As raízes financeiras do investimento direto estrangeiro: notas sobre a experiência brasileira recente. Ensaios FEE, FEE, Porto Alegre, v. 20, n. 2, p. 81-128, 1999.

VITALI, S.; GLATTFELDER, J. B.; BATTISTON, S. The Network of Global Corporate Control. 2011. <http://arxiv.org/pdf/1107.5728.pdf>.

Recebido em 10 de outubro de 2017. Aceito para publicação em 04 de janeiro de 2019. 